\title{
One Continent, Two Federalisms: Rediscovering the Original Meanings of Australian Federal Ideas
}

\author{
Dr A. J. Brown* \\ Key Centre for Ethics Law Justice and Governance, \\ Griffith University
}

\begin{abstract}
Federalism is usually described in political science as a single body of ideas, in Australia's case arriving in the 1840s-1850s and moving to constitutional reality in the 1890s. However Australia also experiences ongoing debate about the wisdom and suitability of federalism, challenging the simplicity of this story, but rarely dealt with by federalist scholarship. This article reexamines the origins and diversity of federal ideas in Australia, questioning orthodox assumptions about their singularity, arrival date and linear heritage. It suggests federal thought began influencing Australia's constitutional development significantly earlier than previously described, beginning with the territorial separation of Van Diemen's Land from New South Wales in 1823-1825 as opposed to subsequent ideas about colonial reunion. This first Australian federalism had a previously unappreciated level of support in British colonial policy and drew on Benjamin Franklin's American model of territorial change as a 'commonwealth for increase'. The revised picture entrenches the notion of federalism's logic in principle, but also reveals a dynamic, decentralist style of federalism quite different to Australia's orthodox 'classic' or compact federal theory. In fact Australian political thought contains not one, but two often conflicting ideas of federalism, challenging the myth of a singular federalism grown out of a landscape of autonomous colonial governments. The presence of these two approaches - along with others - helps explain longstanding dissent over the regional foundations of Australian constitutionalism.
\end{abstract}

* Research Fellow, Key Centre for Ethics Law Justice and Governance, Griffith University, Brisbane. Email A.J.Brown@griffith.edu.au. This article is an adapted version of a refereed paper delivered to the Annual Conference of the Australasian Political Science Association, Hobart, October 2003. Thankyou to conference participants, particularly Rod Rhodes and John Wanna, and my anonymous reviewers for comments. 


\title{
One Continent, Two Federalisms: Rediscovering the Original Meanings of Australian Federal Political Ideas
}

\author{
A. J. Brown
}

\section{Contents}

\section{Introduction}

2. The Dating Game: When Did Australian Federalism 'Arrive’?

The conventional story: Sydney, free trade and Imperial 'consolidation'

The 'Commonwealth for Increase': British policy and territorial fragmentation

Territory, federalism and colonial expectations

Federalism and early Australian nationalism

\section{One Federalism or Two? Explaining the Hidden Story}

Why has history neglected Australia's first federalism?

Australian federalisms' differing mobilisational orientations

Reviewing Australia's second federalism: how 'federal' is it?

\section{Conclusions: A New Approach to Old Enigmas}

5. References

\section{Introduction}

When did federal ideas first begin to take shape in Australian political history, influencing the development of its political institutions? What was the content of these ideas and why, after many generations, do these questions matter? This article argues that both timing and the content of Australia's reception of federalism are vitally important not only to our past, but present and future political structure. This is not least because modern Australian political science and constitutional history may have so far got these basic elements of our federal story quite wrong. Whereas conventional scholarship records federalism as making its debut in 1840s discussions in Sydney and London, a fresh and critical examination of Australian political ideas reveals federalism to have made its entry at least 20 years earlier, in a manner that continues to have different, powerful effects. The discrepancy is explained by the fact that these two periods saw the entry of distinctly different types of federalism, with only the second dominating more recent analysis, despite the great importance of the first wave of ideas and the unresolved interplay between them.

The first part of the article broaches the question of when federal ideas made their Australian debut, reviewing the conventional account of federal ideas as having 'arrived' in the 1840s. It 
goes on to identify three significant problems with that account, unlocking in its place a substantially different story based on a reanalysis of territorial ideas in Australian constitutional history (Brown 2003). On this new account, core developments in British policy and colonial politics by the 1840s had already been driven by federal notions for quite some time - notions with great significance both for Australian politics and the evolution of modern federalism worldwide. The second part of the article goes on to examine the implications of this basic factual revision, beginning with why Australia's first body of federal ideas has gone largely unnoticed, how it has evolved and where it now stands in relation to the orthodox story.

This analysis leads to the conclusion that two distinct bodies of ideas were involved, with the new analysis describing not simply an earlier but different federal idea than that of the conventional story; in fact, our orthodox picture of federalism begins to look far less 'federal' by comparison. The article concludes by summarizing the key differences between the traditions, and their broad implications for contemporary Australian political science.

\section{The Dating Game: When Did Australian Federalism ‘Arrive'?}

\section{The conventional story: Sydney, free trade and Imperial consolidation}

Our familiar story of Australian federalism begins in the early 1840s. By this time there were four Australian colonial territories: New South Wales, founded in 1788; Van Diemen's Land, separated from NSW in 1825; Western Australia, annexed in 1829; and South Australia, separated from NSW in 1836 (Figure 1). Modern political science describes the path to these and later territorial divisions as an inevitable process, in which "a single hierarchical governing structure, suitable for the early prison administrations and Crown control of land settlement, was quickly found to be quite unsuited" to Australian geography (Holmes \& Sharman 1977: 12-14; also Sharman 1987: 42-3). As a result, new territories "broke from the mother colony” (Irving 1999a: 2); as put by Holmes and Sharman, sovereign political authority was "fragmented" between "regional centres" as the result of a "movement away from a centralised and tightly organised society of administrative officers towards freedom and decentralization”. On this account, territorial fragmentation is often seen as an inevitable reaction against an original centralized British preference and theory. 
Figure 1. Anglo-Australian boundaries 1783-1851
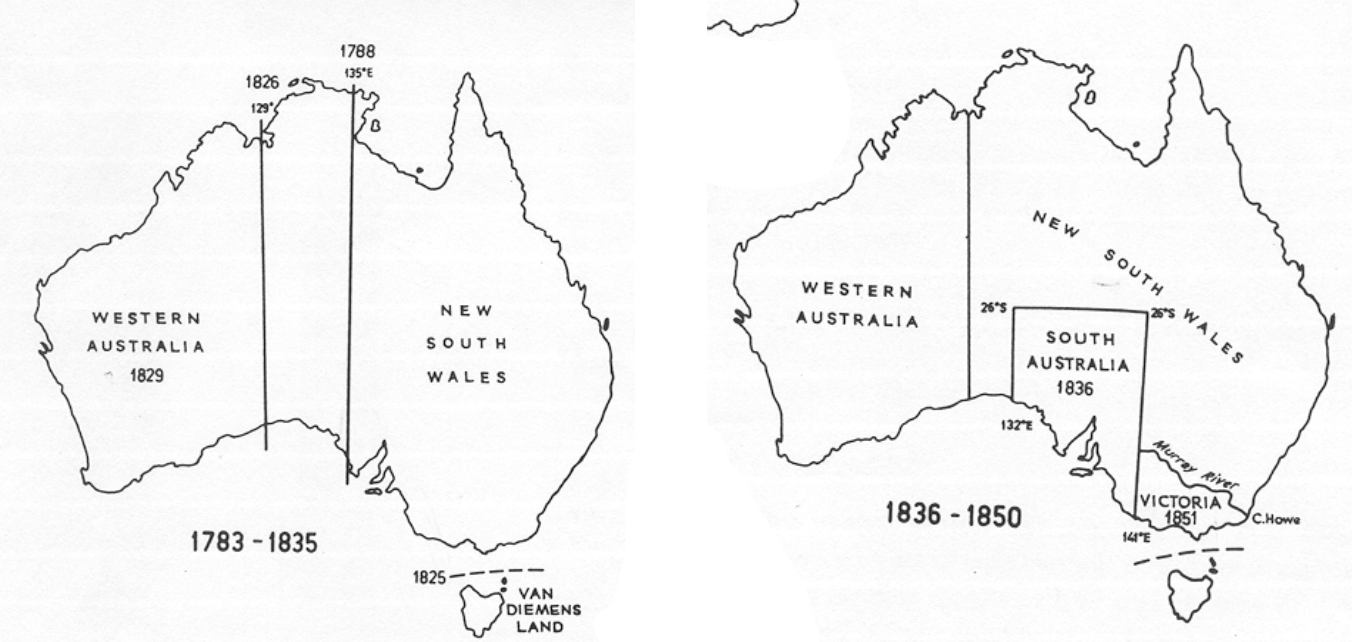

Source: Jeans (1972: 11), see also McLelland (1971) cf Macintyre (1999: 96).

By the early 1840s, nevertheless, some colonial leaders were seeking methods of rejoining the four colonies at least for limited purposes. On the orthodox story, this was when federal ideas made their entry, marking "diversity in unity" as "the pattern of Australian government from its earliest settlement” (Holmes \& Sharman 1977: 12-14). The sentiment for unity has been traced to a law sought in 1842 by the early NSW Legislative Council, attempting to preserve Sydney's role as the colonial commercial hub by ensuring duty-free trade with Tasmania and New Zealand. While a locally-legislated free trade union was disallowed as beyond power, continuing support led in 1846 to an official proposal by the NSW Governor, Sir Charles Fitzroy, that a "superior functionary" such as a Governor-General be appointed to ensure consistency in "all measures... affecting the general interests of the mother country, the Australian colonies, or their intercolonial trade” (quoted Wentworth 1956: 8-9). The NSW colonial secretary Edward Deas-Thomson, originator of Fitzroy's proposal, has been described as "par excellence the Father of Australian Federation" (Cramp 1914: 123-6; see also Irving 1999a: 3-4, 24, 357-8, 430).

In London, in the same year, the return of a Whig government saw firm moves towards a formal intercolonial union, combining the need for colonial constitutional development with its policy of maximum Imperial free trade. In 1847-1850, in the New Zealand and Australian Charters and Australian Constitutions Bill (No. 2), Earl Grey’s administration twice proposed the four colonies be joined in a national or 'general' assembly (Earl Grey 1853: 317-23, 4278; Egerton 1893: 284; Cramp 1914: 122-7; Ward 1958: 23; Melbourne 1963: 275-351; Sawer 
1969: 6-7; McMinn 1979: 92; McKenna 1996: 110-1). However we conventionally see these early proposals for union as having failed because Australians were simply not yet prepared to think nationally (e.g. McKenna 1996: 59). For example, the Europeans who settled Port Phillip in 1835 were focused on achieving their own separate status as a colony; only after achieving territorial separation in 1851 did they develop their interest in union (Quartly 1999: 221-3). Britain's grants of responsible government placed what had become five (then six, with Queensland in 1859) colonies on a delayed path to federal union, because from the mid1850s these all became "quasi-sovereign bodies, politically independent of each other” (Joske 1967: 34; see also Irving 1999a: 2). Continuing this early political immaturity and natural parochialism, the idea of Australia as a national 'dominion' within the Empire was also slow to take hold. It was three decades before progress resumed towards the long-awaited union, by which time it had become "hardly surprising, given the political history and geography of established self-governing colonies” that the nation took the form of a federation (Galligan 1995: 32, 52-5; see also Hirst 2000: 1; Saunders 2001: 133).

Despite its great familiarity, this orthodox story of Australia federalism raises several questions not answered by modern political science. It is generally a neat, linear story - in fact, it remains typical of the teleological metanarrative or "forced march" of Australian history as progress towards nationhood that some have long suggested should be abandoned (McCarty 1978: 104). It provides little insight into the source or character of the federal ideas that appeared in the 1840s, much as it has never dealt with other possibilities - such as that federal ideas might have been locatable in Indigenous Australia, among the continent's “oldest political units” of Aboriginal and Torres Strait Islander frontiers and boundaries (Davis \& Prescott 1992: xi), as suggested for Iroquois influences on American federalism (Morris 2001: 293-4). If we regard the characteristic feature of federalism to be governance through "non-centralised networks" and "matrix-style processes" (Fletcher 1998: 36, citing Elazar 1997), indigenous constitutionalism might provide a very old/new starting point for our interpretation of Australian federalism.

However even in British history, our conventional story of a singular, linear body of federal ideas has at least three problems. Taking these in turn, we unlock a more complex account of how federal ideas influenced the development of Australian institutions not just from 1842, but from an earlier stage and in different ways. First, we find indications that British colonial policy was pursuing federal options at least 20 years earlier; second, we find earlier evidence 
of actively federal expectations among civilian colonists; and third, throughout this early colonial period we find signs that ideas of Australian nationhood were better established than our modern conventional story suggests. From these historical adjustments flow new implications for the way in which modern federalism unfolded on a worldwide basis, as well as the conclusion that not one but two theories of federalism were at work in early AngloAustralian politics, our recent view dominated by the later arrival.

\section{The 'commonwealth for increase': British policy and territorial fragmentation}

The first key to unlocking the story is the assumption that British authorities were originally inclined against Australian territorial fragmentation, but at something of a loss to prevent it. In reality British colonial policy was not so blind, particularly given its education in the spatial dimensions of North American colonial politics before, during and since the 1776 Revolution. After all, the loss of so many American colonies was "a trauma the British could never forget” (Hyam 2002: 53), and Australia was part of an ongoing colonial story still overshadowed by that experience. British supporters of Australian development commonly saw Australia's destiny as replacing the lost opportunities of the first New World, typified by Sir Joseph Banks' vision of “empires and dominions which now cannot be disappointed... who knows but that England may revive in New South Wales when it has sunk in Europe?” (1797, quoted Manning 1966: 287). In British policy, theories of territorial fragmentation and unity were alive and well, particularly since American federalism had revolutionized emerging European concepts of nationhood with its "first sustained and principled counterargument” for local/regional “legal life” (Blomley 1994: 114).

From the outset, Australia's early divisions seem unlikely to have been shaped purely as a reaction by centralist British officials to new colonial experience, without reference to America. Indeed British authorities were in no way 'forced' by Australian conditions to abandon their preference for a single administration, but rather did so deliberately and willingly. The preference for centralized control had only arisen with the Revolution, and only lasted until 1817-1819 when the British government resumed its colonial program after the Napoleonic Wars. The original centralist orientation in NSW administration reflected neither more nor less than the British policy of only establishing new colonies under tight military law, circumventing questions of political representation and civilian rights (Manning 1966: viii, 287-99; see also Egerton 1893: 258-60). After the Napoleonic Wars, British attention quickly returned to the political elements of developing the post-Revolution 
possessions. Just as Singapore was founded in 1819, so too came that "landmark in Australian history”, the colonial policy inquiry of J. T. Bigge, and Australia's first significant constitutional and territorial developments since foundation 30 years before (Manning 1966: 539, 525-40). In 1823, the Act for better Administration of Justice in New South Wales and Van Diemen's Land, and for the more effectual Government thereof, simultaneously 'civilianised' the Australian administration and provided for its decentralization through formal separation of Van Diemen's Land, decisions fundamentally interlinked in the new British policy (Clark 1962a: 341, 373-4; Lumb 1991: 19, 33). Against the Australian myth that Van Diemen's Land was legally separated once discovered to be an island, or because its settlements proved difficult to manage, it had already been known to be an island for 24 years and its settlements had grown stably for almost as long (Melville 1835: 18; Clark 1962b: 1224; Blainey 1966: 76-7; Robson 1989: 84-94; Shaw 1989: 202-5). Territorial policy and constitutional direction changed less because of Australian circumstances than the basic reorientation of British policy.

What was the influence of federal ideas in this reorientation? Much Australian history is dominated by an assumption that Britain looked with embarrassed distaste on the United States’ immediate post-revolutionary development - but in fact the British territorial strategy appeared to directly reflect North American experience, and particular respect for American federalism. There are both general and specific reasons to believe that the British authorities' new policy of territorial subdivision was fully consistent with a federal strategy. Whereas Britain's American colonies had emerged in a largely unplanned pattern, since galvanized by the Revolution into two groups (the federated United States and British North America), New South Wales provided the opportunity to establish a new collection of civilizing colonies with more complete knowledge of how the group might develop. British authorities were determined to prevent any repeat revolution, but otherwise remained deeply interested in the 'Great Experiment', not only for the new republic's political lessons but because the countries remained "intimately connected" in what was still a "single Atlantic economy" (Hyam 2002: 54). This interest included rapid development of the idea of colonial nationhood or 'dominion' status - the idea of sub-imperial nations, federal or otherwise, reputed to have only developed later in Australia. Loyal American elites had raised dominion status as a means of preventing the Revolution, without any intelligent British response (Jensen 1940: 108; Rossiter 1953: 306-8, 339-41). British consciousness that its remnant colonial groups should be managed this way had since leapt to the fore, with British North America quickly 
reconstituted as a 'national' group, albeit to bolster, not concede British sovereignty. Lord Dorchester, appointed as Canada's first Governor-General in 1786, soon affirmed that "the Policy which lost those great [US] provinces can not preserve these scattered and broken Fragments which remain” (1793, quoted Manning 1966: xiii, 36-7; Keith 1938).

Even more important than a model for retaining British territories, were the positive advantages demonstrated by American federalism for colonial development. Post-revolution America was booming, and the territorial pattern under the new federalism was integrally involved. By the early 1820s, the thirteen original United States had grown in number to 24, and the number was still growing as old territory was subdivided and new territory acquired. The progressive roll-out of new state governments both matched and assisted the colonization and population of territory. Indeed like dominion status, the theory that continental union could work in support of this kind of territorial change had already been circulating for several decades. Benjamin Franklin’s 1754 Albany Plan had identified the advantages of union as including a collective capacity to create new governmental administrations, thereby facilitating more efficient colonial development; Franklin wrote that whereas "a single old colony does not seem strong enough to extend itself otherwise than inch by inch", an intercolonial union could work as a "commonwealth for increase" (quoted Beer 1993: 155-8, 354-5). A central government could grow the national wealth by securing the territory presently unusable by individual colonies, grant the land to settlers, organise new governments and ultimately admit them to the Union under what became Article IV of the 1787 Constitution. In practice this mechanism was not established as neatly as it appeared (Jensen 1940), but the American trend from 1781-1783 nevertheless followed Franklin's principles, making territorial dynamism, economic development and federalism all synonymous (Bryce 1889: 343; Glassner 1993: 155). From the post-revolutionary period to the American civil war, British authorities recognized modern federalism's colonial lessons as spectacular. As late as 1852 William Gladstone described America as "the great source of experimental instruction, so far as Colonial institutions are concerned", while the radical politician J. A. Roebuck was one of many to specifically admire the American federalism's ability to self-expand by creating new states:

The whole thing was like a well-made watch - it went from that moment [in the 1780s] and never ceased to go (Roebuck 1849, quoted Cell 1970: 89-90; Hyam 2002: 54). 
In Australia in the 1820s, then, it becomes more understandable why British policy makers would decide not just to support new settlement, but create new colonial territories. The 1825 separation of Van Diemen's Land from NSW, as recommended by Bigge and enabled in 1823, was a conscious first step down a particular constitutional path. When the island's new Lieutenant-Governor, George Arthur, was despatched for his post in late 1823, this path was foreshadowed in advice from James Stephen, the colonial office counsel of 10 years' standing, main architect of the 1823 Act, and soon to be permanent under-secretary for the colonies (see Crowley 1955: 49-50; Pike 1957: 35; Ward 1958: 22-9; Manning 1966: 77; Cell 1970: 915). Stephen told Arthur to shape the new colony as:

one branch of a great and powerful nation, which must exercise a mighty influence for good or evil over a vast region of the earth... Christian, virtuous and enlightened (James Stephen 1823, quoted Clark 1962a: 373).

Van Diemen's Land was to be not just another British colony, therefore, but the first of the necessary 'branches' needed to build the new British South Pacific nation. The intent for these branches to remain linked as a national group was confirmed by the legal form of Arthur's appointment. Though we customarily believe that Van Diemen's Land was made independent of New South Wales, and Arthur thereafter "dealt directly with... London" (Townsley 1991: 37), Arthur's formal commission was as constitutional junior to the new NSW Governor Sir Ralph Darling, who in turn retained commissions as "Governor-in-Chief to the island of Van Diemen's Land" and "Captain-General" of both colonies (see Melville 1835: 52; Wentworth 1956: 8). At least on paper, Darling was to Australia what Dorchester was to Canada - a Governor-General of the kind, on the orthodox story, supposedly first mooted 20 years later.

Together these features of the separation of Van Diemen's Land suggest an actively federal intent, because whereas an ex post facto nationalist grouping in Canada was elemental to retaining British North America, British Australia was a clean chart on which the first new territorial unit of a whole future nation had now been marked out. Australia was like the American west, or at least the romanticized notion of the American west held by British officials - a landscape as yet undivided to British eyes, in which a territorial pattern of multiple colonies could now be established specifically to join and grow in federal fashion. Only rarely has this possibility been canvassed in Australian political history, such as in Irving's (1999b: 2) remark that "the idea of joining the unwieldy Australian colonies together had been in the minds of officials... even before the division of the colonies”. Perhaps Irving meant only that the federal idea appeared before the process of colonial division ceased, in 
1859-1861; but in any event we can now take these words literally, because it seems inescapable that federal ideas were influencing policy even before subdivision began.

\section{Territory, federalism and colonial expectations}

If British policymakers were not 'separating' territory as much as reconfiguring it in the first steps towards a federal nation, how do we assess historical assumptions that early Australian colonists knew nothing of this, interested only in their own autonomy? This second major problem of our conventional federal story presents the post-1820 fragmentation of territory as a reaction to centralized British preferences, reflecting a "movement towards freedom and decentralisation” within fledgling colonial politics (Holmes \& Sharman 1977: 12-14), with no idea that colonial desires for subdivision were more than parochial. Analysis of the multiple strands of early colonial politics tends to leave this presumption untouched, noting debate over disposal of land but not over the allocation of territory (Hume 1994: 28). On the conventional account, therefore, the federal idea only made its entry from the early 1840s in response to fragmentation, rather than being embedded in that fragmentation itself.

The problem with this view of colonial expectations is similar to that of official policy. If American developments were naturally high in the minds of British colonists in early Van Diemen's Land (e.g. Warden 1999: 191-3), then why would settlers see new jurisdictions purely as separations and not also as steps towards a federal nation? In fact there is evidence they did see the development thus, evidence which continues through subsequent divisions and is particularly clear in the Port Phillip campaign for statehood.

In Van Diemen's Land, the federal idea was at least indirectly evident in the manner in which the settler population called not just for separation, but 'independence'. Consistently with Franklin's idea of federalism as a 'commonwealth for increase', the separation reflected a 'bottom-up' process of political and economic self-identification, as well as ‘top-down' ideas about colonial planning. The confidence with which the colonial office set about legal separation of the island was matched by colonist confidence in this political destiny. In April 1824, apparently unaware that Arthur was already en route with instructions for the separation, "landholders, merchants and other inhabitants" gathered in Hobart and petitioned the King to "elevate Van Diemen's Land into a separate and independent Colony" in the terms of the 1823 Act (see Melville 1835: 20; Ellis 1933: 19-20; Clark 1962b: 122-4). This ‘independence' claim reflected the Vandiemonians' desires for a free economic hand, but almost certainly was also made with an awareness of how the federal system was unfolding 
within and across American territory. As Warden indicates, from the outset the Australian settlements were linked to the United States not only through British experience, but directly in a "Pacific economy" dominated by American shipping, with Hobart particularly wellknown as a summer (winter) base for New England fishing fleets (Hyam 2002: 55; see also Melville 1835: 7, 160; Greenway 1972: 77-8; Robson 1989: 87, 93). Given the many indications of American influence, it seems impossible that the Vandiemonians failed to relate their separation from NSW, as Australia's first new colony, to Maine’s 1820 separation from Massachusetts as America’s tenth new state (see generally Banks 1973).

In the next territorial decision, Britain's 1829 annexation of Western Australia, the constitutional intent is less clear. There was no preexisting community of European settler interests, and the Swan River colonization project was "almost accidental and largely unplanned” (Statham 1981: 181-9; cf Davis 1987). However in the creation of Australia's fourth colonial jurisdiction, there are strong signs of a federal influence. South Australia's enabling Act of 1834 for "a British province or provinces" not only employed the same subcolonial term used in British North America, but conspicuously implied there could be more than one new territory. These were terms drafted and negotiated into law by South Australia's ready-to-depart settler community rather than proclaimed from on high. As with Tasmania, formal links also remained with the parent territory which have since disappeared from historical view - such as the fact that even a decade later, official British descriptions of South Australia identified the province as still "part of Our said territory" of the colony of NSW (see McLelland 1971: 673; Howell 1986; Lumb 1991: 30).

It is in the foundational politics of Victoria that the character of these first federal ideas becomes clearest of all. In parallel to the imminent foundation of South Australia, the 'bottom up' political dynamic that founded Port Phillip (Melbourne) was substantially a replication of the separation of Van Diemen's Land. From the late 1820s, it was in Van Diemen's Land that pressure mounted for pastoral runs to be released on Bass Strait's northern shore, leading to the Henty family's founding of Portland in 1834 and the larger annexation of Port Phillip by John Batman's Port Phillip Association in 1835 (Roberts 1924: 205-7; Greenway 1972: 85-6; Kociumbas 1992: 119-23, 179-90; Shaw 1989: 207-13). Batman's tactic of 'buying' 600,000 acres from their Aboriginal owners directly mimicked proven American frontier experience, thereby forcing an 'official' grant. Even more importantly, in terms of federal theory, the Port Phillip investors did not stop at formal 
recognition of their property rights, but immediately from March 1836 also sought proclamation of a whole new colony (Melbourne 1963: 331-4). The Port Phillip campaign for political territory was to last 15 years, a period in which "all other political ideas" took second place against the goal of territorial autonomy (McMinn 1979: 35; see also Melbourne 1963: 283-356; Garden 1984: 63-8; Priestley 1989), but in which it is not safe to assume that there was no federal instinct.

The nature of the federal idea in colonial politics at this time was twofold. Yes, colonial communities were now seeking their own territorial autonomy; but they were doing so within an expectation that such autonomy accompanied the development of the nation. Like Van Diemonians and South Australians, the Port Phillipians did not turn to ideas of intercolonial union after they achieved separation in 1851. Instead, their leadership apparently saw colonial separation as fully consistent with, and the path to an Anglo-Australian nation. Direct awareness of America's growth remained strong in fora such as the early Melbourne chamber of commerce - reportedly dominated by Americans (Hyam 2002: 55). By the late 1830s, de Tocqueville's Democracy in America had appeared, immediately translated and distributed throughout the Empire, complete with its comparison of America's growing number of state governments to "companies of adventurers, formed to explore in common the wastelands of the New World" (de Tocqueville 1835: 295-7, 398; see Blomley 1994: 120-1; Hyam 2002: 53; Patapan 2003: 3, 6). Any doubt about the currency of this federal vision at Port Phillip is dispatched by the role of its future separationist statesman, Sydney's John Dunmore Lang (see generally Ellis 1933: 48, 57; McKenna 1996; Irving 1999a: 391-2). In November 1841 Lang's first fundraising visit to Port Phillip found him regaling separationist audiences with his experience of a recent 10-week trip to the eastern United States, during which he had himself read de Tocqueville. Though not yet republican, Lang assured the people of Melbourne that their campaign accorded with the driving force of America's progress: its spontaneous internal subdivision into small democratic states (Baker 1985: 165201, 290-343). With this strong justification for territorial autonomy backed up by federal political theory, Lang's popularity at Port Phillip appeared sealed.

Port Phillip's would not be the last such separationist campaign in Australia, as will be discussed. But the important feature is that the tradition already established by the early 1840s was not merely separationist, but also explicitly federalist in character. These territorial units were seen by aspirant citizens as the building-blocks of the new Anglo- 
Australian nation. In a manner strongly resonant with Franklin's original concept of a 'commonwealth for increase', separation was not a stand-alone idea but rather an integral part of the federal concept, with the granting of local legal autonomy, capacity for economic development and national union within Empire all working together.

\section{Federalism and early Australian nationalism}

The third key feature of this alternative early federalism, by contrast with the conventional story, has already been hinted at: the signs that Anglo-Australian colonists were conceiving themselves as the founders of a new British nation long before the last decades of the $19^{\text {th }}$ century when that nation was finally negotiated. It is in the 1880s-1890s that we customarily regard the Australian nation has having been first properly “imagined” (Irving 1999b: 25ff). This view is also naturally central to our idea of Australian federalism, because the union then negotiated was inevitably federal in much of its form, implying that federal ideas must therefore also have previously been weak.

However we have already seen signs that concepts of nationhood generally, and federal nationhood specifically, were embedded in the foundational expectations of colonists from half-a-century earlier. Given the longer history of dominion concepts, intercolonial legalism and popular federalism mentioned above, it becomes unlikely that the proposals for union in the 1840s failed to take hold because Australians were unprepared to think nationally. After all the plainest single cause for failure of the 1849-1850 proposals was their rejection by an uncooperative House of Lords as a "rash and perilous innovation” (quoted McMinn 1979: 467). In Australian debates about responsible government in 1850-1855, the concept of a national constitution - as opposed to simply separate colonial ones - was routinely supported in principle, and popularly in substance. Continuing faith in nationhood was evident in Van Diemen's Land, where the Hobart Town Courier regarded the Australian colonies as already “States confederated” (1853; see McKenna 1996: 73), and there was public support for a single constitution achieving an Australian “confederation” (see SMH 1853a). The NSW Legislative Council maintained its call for a general assembly of the colonies (NSW Legislative Council 1853a: 121-2; Wentworth 1956: 7, 10), and when this failed to eventuate, the Sydney Morning Herald condemned the new separate constitutions for encouraging "huckstering notions of statesmanship", ensuring all colonies would legislate against each other "like rival tradesmen competing for custom” (SMH 1857 quoted Ward 1958: 465). Against the noble standard of "a form of Government based on the analogies of the British 
Constitution” (NSW Legislative Council 1853a), to which all aspired, to have colonies not grouped as a nation appeared rather strange. A group of Shoalhaven landowners stated the obvious when they petitioned the NSW legislature for an intercolonial conference "to prepare one Constitution for Australasia”:

[I]t appears to your Petitioners strange and unstatesmanlike, as well as a most unseemly and untoward system of patchwork legislation, that Australasia, comprising but four Colonies, Dependencies, not far distant from each other, peopled by the same race, British subjects too... shall be doomed to have no less than four Constitutions. The great study and aim of all practical British Statesmen is not only to have and preserve one British Constitution, but also to assimilate the local laws of England, Ireland, Scotland, and Wales, as being most conducive to [inter alia] the social and political harmony of the people (see NSW Legislative Council 1853b; Cramp 1914: 128-9).

The Sydney Morning Herald's constitutional correspondent similarly seemed to roll lack of vision, lack of democratic commitment and lack of federal unity into his poor assessment of the NSW drafting process:

Oh, for a Washington, or a Franklin! - But we may sigh in vain (SMH 1853b).

Even later when social factors, political forces and world events provided the conditions for Federation, it is not necessarily accurate to assume that Australian nationalism had to be created or recreated over a short period. For the colonial legislators whose own power and interests were closely aligned with their jurisdictions, nationalism was clearly often a secondary consideration, and had to be negotiated into existence. Popularly and objectively, however, memories seemed to have persisted that the original subdivisions were not conceived as 'independent' but rather as subnational units, as displayed when Sir Samuel Griffith told constituents that in reality no individual colony could honestly claim its own permanent "feeling of Patriotism" or expect to stand "permanently distinct in the eyes of the rest of the world" (Griffith 1891: 72, 76). The substantial lack of excitement around Federation even in the 1890s perhaps had much to do with the fact that this idea was already well established in the public psyche. It took until the 1880s-1890s for formal territorial unity to be restored, but it seems the unifying as well as separating principles of federal sentiment had already been entrenched much earlier in colonial society. 


\section{One Federalism or Two? Explaining the Hidden Story}

\section{Why has history neglected Australia's first federalism?}

The revised account of federalism's earliest Anglo-Australian manifestations, suggested above, pushes the reception of federal ideas earlier by at least 20 years, taking it to the very front of early colonial development. While this possibility requires further study, its neglect so far in Australian political history needs some explanation along with rectification. Australian scholarship often rings loud with assurances about federalism's naturalness as a governing strategy for the continent, not least during the recent centenary of Federation. But if so, why have these first major manifestations of federalism in Anglo-Australian history gone under-detected? On one analysis this question matters little, since evidence of an earlier reception of federal ideas seems only to entrench their general naturalness. However it is possible that elements of our political culture have also been lost with the earlier story.

The need for a theoretical reconciliation of the different stories is emphasized by the stresses that show in Australian constitutional history, even without the new federalist account. One reason for loud defence of federalism has been the prevalent attacks on its territorial logic, including $20^{\text {th }}$ century arguments against federalism's divided sovereignty per se and in toto. Australians' relationship with federalism is somewhat 'love-hate', with Galligan describing collective understanding of federal experience as frequently "schizophrenic", resigned to the likelihood that "so long as Australia has a federal system there will probably be critics calling for its abolition” (Galligan 1995: 9, 53-62). While the schizophrenia is partly explained by a “dual constitutional culture” (Galligan 1995: 46-51; Warden 1992: 143) in which majoritarian (implicitly centralist) traditions of British responsible government are presumed to sit in tension with federalism, this tends not to explain the whole problem. Anti-federalist criticism in Australia is often based not in the view that the political system should be more centralized, but rather that it is too centralized - paradoxically, that a more effective decentralized structure should be achieved by abolishing the states (see Crisp 1978: 23ff; Galligan 1995: 91ff; Macphee 1994a; 1994b; Hall 1998). But this anti-federalist criticism also has much in common with the federalist political tradition described above, embedded in Victoria’s separation in 1851 and which continued successfully at Moreton Bay in 1859, and less successfully in continuing, virulent separation and 'new state' movements such as those of New England, the Riverina, central and north Queensland (Holmes 1932; Ellis 1933; Neale 1950; Kidd 1974; Belshaw 1982; Figure 2). These movements had their own effects on the 
Federation process, as reflected in Chapter VI of the Australian Constitution (Parkes 1892: 580-613; Wood 1933: 232-3; Nicholas 1951; 1952: 95ff; Bolton \& Waterson 1999; de Garis 1999; Irving 1999b: 141-2, 191, 197; Brown 2001a), and they continue to resonate (e.g. Blainey 2000; 2001). This confluence of early but forgotten federalism and more recent antifederalism tends to indicate something unfinished in Australian constitutional development, at least against emphatic assurances that today's version of federalism was inevitable, and stands fixed and final (cf Page 1917; 1963: 382-3; Brown 2001b).

Figure 2. Proposed new states of Australia 1850s-1960s

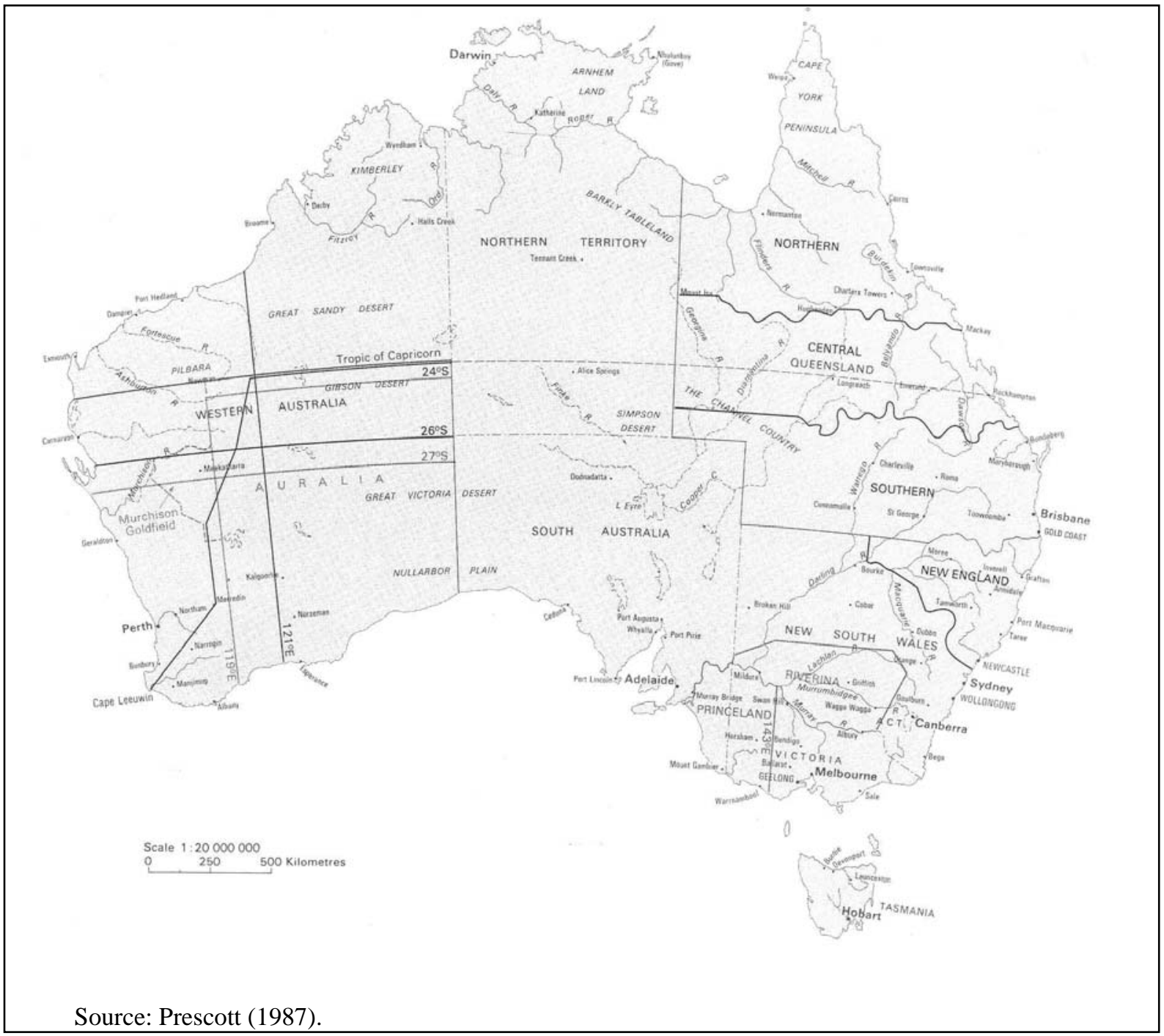

There appear to be some simple reasons why the earlier arrival of federalism might be overlooked. First, the British colonial office did not adhere for too long to the original 'Franklinesque' concept of subdivision in the 1820s. Notwithstanding admiration for 
America, official policy was moving from territorial fragmentation back to 'consolidation' as a preferred option for its colonies (e.g. the forced reunification of Canada in 1840: see Ward 1958: 41-3; Martin 1972; McMinn 1979: 36; Knox 1971: 578). 'Britishness' was also growing in $19^{\text {th }}$ century Australia in a manner that tended to submerge the validity of American political ideas even where previously influential, until selectively revived at Federation. Further, the key sites for enunciation of Australia's first federal ideas were not Sydney or London, where official elites assembled and records were kept, but communities closer to the periphery of geography and history.

Nevertheless there is also a more complex reason why early Australian federalism has been neglected: the fact that its decentralist tradition is quite different, and at times inconsistent with that conventionally celebrated as arriving in the 1840s. Rather than reconciled or assimilated, the first federalism appears to have been in tension with, and later obscured by, the ideas of intercolonial union that emerged thereafter. This relationship not only helps explain why the first might go unnoticed, but calls for a more theoretical appraisal of these ideas' content. Such an appraisal reveals, first, that the ideas are indeed different, with the earlier federalism more significant than previously realized; and second, that there may be limits to the extent that Australia's second 'federalism' should even be considered 'federal'.

\section{Australian federalisms' differing mobilisational orientations}

In comparative constitutional analysis, there are two main means of comparing federal systems and ideas: usually by reference to comparable institutions, but also through theoretical analyses such as the 'mobilisational orientation' of their formation and configuration (King 1982; Watts 1996). On King's analysis orientation typically refers to intended levels of decentralization, centralization or 'balance'. Using this approach, Australia's conventional federal story is based - like many federal stories - on an orientation of partial centralization: from 1842, it began to be suggested that separate territorial units (then four, later six original colonies) should unite while also preserving existing identities. This 'classic' orientation was present in American federalism, but also predated it, in concepts of territorial compacts often traced by Europeans back to Ancient Greece (e.g. Freeman 1863: 72; Galligan 1981: 130; 1995: 39; Beer 1993: 223; Elazar 1997: 249); it is embedded in the standard definitions of federalism derived from the Latin terms foedus (treaty, agreement or compact) or fidere (trust) with which separate communities share their power under joint constitutions (Kidd 1957; Riker 1975: 99; Holmes \& Sharman 1977: 21; 
Walter \& Huebsch 1978; Davis 1978; Harman 1992: 337). The orientation is one of partial centralization because the focus at federation is on the nature and extent of powers to be relinquished by constituent governments to the central one.

However, another mobilisational orientation can also be seen in the federalism imported into early colonial Australia, in the form of Franklin's idea of the 'commonwealth for increase'. Franklin's theory saw union as also immediately concerned with structural decentralization, based on the principle that both mobilisational orientations - centralization and decentralization - could and should work together. Australian colonists who saw territorial separation and national union as one and the same, clearly adopted this principle. Examples include not just Lang, but the famous declaration by Queensland's colonial secretary, John Macrossan, to the Melbourne Federation Conference that "the strongest separationists are the most ardent of federationists” (Melbourne Conference 1890: 12 February 1890, 72). The Central Queensland separationist, George Curtis, accurately summarized America’s federal dynamic as a process of "separating and federating the whole time” (QPD 1899: 35). Indeed the full significance of the first federalism conceived pre-1842 becomes clear when appreciating the variation entailed by the transfer of the model. Franklin's combination of orientations involved a sequence of territorial centralization in order to then immediately begin a process of territorial decentralisation. But in Australia, the reception of federal ideas involved a slightly different orientation again: decentralizing first on the understanding that a federal union would naturally follow later. For the first time in European history, the Australian sequence tended towards the division of territory not to create new 'colonies' as in previous experience, but deliberate propagation of subnational units for a future nation. The new Australia was comparable to the American west, where great expanses of territory were subdivided into the states that made the nation, except that in Australia no central national authority yet existed; the Australian process began in 1823 with one original jurisdiction as opposed to the United States' 13-or-more. Never had Europeans tried this 'Franklinesque' idea of federalism from scratch. The fundamentally decentralist Australian orientation is therefore historically important in its own right - an experiment on an experiment, more significant than previously realized in the world history of federalism.

Australia's first federalism nevertheless came up against an alternative idea - still federal, in that it envisaged a compact between existing territories, but not recognizing further territorial decentralization as an objective. The Sydney and London ideas from the 1840s reverted to 
the singular mobilisational orientation of partial centralization. A significant historical tension thus arises from the fact that many colonial and regional communities always continued to see federalism as capable of jointly fulfilling both orientations, as testified by 'new state' activism, trying to satisfying demands for both a high level of national unity and serious political decentralization. This first federal tradition therefore retains a significant political potency should its dual orientation again be recognized, and enjoys a natural synergy with other theories of territorial reform (federal or otherwise); but it stands in direct tension with the dominant theoretical explanation of the Australian federal system.

\section{Reviewing Australia's second federalism: how 'federal' is it?}

Finally, the differentiation between a first decentralist federalism and a second, more centralist 'compact' federalism suggests some need to reevaluate the latter. When these ideas coincided in the 1840s-1850s, did their adherents even recognize each other as 'federal' and if so, with what associations and implications? In the 1890s, when movements for national union revived, it appears that both veins of federal theory intermingled and that the 'compact' idea was explicitly recognized as federal - it entailed partial, but certainly not total centralization. Fifty years earlier, however, it was not quite the same. Indeed despite the conventional assumption that official 1840s proposals for intercolonial reunion were necessarily 'federal', it seems to be only rarely - possibly never - that the major Sydney and London adherents of reunion used that term. Deas-Thomson's proposal for an intercolonial 'superior functionary' was directed not to the federal but 'general' interests of the colonies, and as a centralizing administrative strategy - without counterbalancing political institutions - it was scarcely federal by later standards. When Earl Grey suggested an intercolonial parliamentary body in 1847-1850, this too was styled a 'general', not 'federal' assembly, and was more consistent with later Canadian than American or Australian federalism by proposing the four provinces send delegates only in proportion to population.

These facts, combined with the proposed sweeping reach of (Sydney-controlled) 'general' powers over trade, tariffs, and control and sale of all public lands, combine to make it more understandable why the South Australian and aspirant Victorians were extremely nervous in 1847-1850 (Pike 1957: 414-6; Ward 1958: 113-37, 179-82; McMinn 1979: 46-7). Their nervousness lay not in inability to think nationally, but more probably in the fact that there was little that was actually 'federal' about the proposals - not just in name, but in their proposed form. Despite being conventionally regarded as comparable to later ideas of union, 
the 1842-1850 reforms would almost certainly have entailed massive recentralisation of legislative and administrative control in Sydney, with the explicit aim of a more politically and economically consolidated colony. British officials at home and abroad, it seemed, no longer wanted a federation as much as almost total territorial reunification.

What then of the colonial discussion about union that promptly followed, in the 1851-1855 debates over responsible government? More historical light may be supplied by the current $150^{\text {th }}$ anniversary of those debates, but there seem to have been significant differences in the way that the desirability of union was perceived in Sydney as opposed to the original 'federalist' colonies like Tasmania and Victoria. Sydney legislators' aspirations appear to have been nakedly aimed at containing and reversing their loss of political and economic control, and did not describe their ideal as 'federal' but rather associated that term with the trend to territorial subdivision recently satisfied for Victoria, and still underway at New England, Grafton and Moreton Bay. As much is indicated by a short dramatic speech by W. C. Wentworth - lead parliamentary supporter of union on Earl Grey's model - in response to a Moreton Bay petition at the same time as the new constitutions were being debated:

[The northern representatives] assumed that the separation of the northern districts was a right, but he (Mr Wentworth) protested against the colony being split up into as many separate governments as people chose to imagine would suit their convenience. ... [He] thought they had too many separations already. The only result of this miserable policy would be that a series of petty, paltry, insignificant, states would be created which would necessitate the creation of a federal Government and end inevitably in the overthrow of the British throne. ... If he had had his way, that brilliant province of Victoria, which was growing up so democratic, would never have been separated at all. ... Was this colony merely to be a sucking nurse to these young states till they could toddle alone, and take care of themselves, and then to part with them? (SMH 1853c; cf Ellis 1933: 54; Fitzgerald 1982: 112)

Far from seeing his own idea as 'federal', Wentworth reserved that term for those following Australia's first federal tradition, and emphatically opposed it. Yet conventional political science and history have always assumed that the Deas-Thomson/Grey/Wentworth notions of union provide the direct antecedents of the federal ideas that spawned the nation. If so, then Australian federalism would in fact appear to have had its genesis in not merely unfriendly, but explicitly anti-federal soil. While the nature of NSW attitudes to union may indeed hold clues to later debates, the fact is that Wentworth's speech also directly confirms the presence in 1853 of the earlier 'true' federalism, in his important 'sucking nurse' question. On the principles of Franklin's 'commonwealth for increase', continuing to play out on the 
Australian frontier, the correct answer to that question had always been 'yes', but Wentworth and his central district colleagues presumed it to be 'no'. Even by the 1850s, the dominant conception of intercolonial union held by Australia's central political elite was directly opposed to the decentralist orientation embedded in popular federalist politics elsewhere in the country. The tension between different ideas was not merely tangential or transitory, but a deep schism that still demands careful scholarly and political attention.

\section{Conclusions: A New Approach to Old Enigmas}

This article has argued that contrary to the conventional story of Australian federalism, ideas about federal structures did not originate in the 1840s-1850s but rather substantially earlier, in different places and with different contents. Figure 3 summarises some of the main distinguishing features between these two distinctive veins of federal thought. Unsurprisingly the appearance of a second federal idea, which subsequently became dominant in expert and academic scholarship, has had the effect over recent generations of obscuring the first. In fact these distinctions make Anglo-Australian events even more significant in world history, because the decentralist components of American federalism that played out in Australia's first federal experiences had never unfolded quite the same way before, even in America itself. By comparison our later, more familiar 'compact' theory of federalism, copied from Canada and the United States with technical care but little innovation, seems less remarkable. Behind recent assumptions that Australian politics have always only been fundamentally pragmatic, utilitarian and materialistic, typified by a federal Constitution drafted by leaders with "little inclination for political theorizing and little apparent need for it" (Galligan 1995: 46; see also Warden 1992: 143), we see instead a more interesting story in which theory and ideas have been important, dynamic and contested (cf Williams 1999; 2001; Patapan 2003). 
Figure 3. Key Distinctions of Australia's Two Federalisms

\begin{tabular}{|c|c|c|}
\hline & Australia’s First Federalism & Australia's Second Federalism \\
\hline Period & From 1820s & From 1840s \\
\hline $\begin{array}{l}\text { Source and route } \\
\text { of ideas }\end{array}$ & $\begin{array}{l}\text { American federal experience, } \\
\text { directly and via British colonial. }\end{array}$ & $\begin{array}{l}\text { American federal, British } \\
\text { unification and Canadian } \\
\text { ‘consolidation' experience, via } \\
\text { British colonial policy. }\end{array}$ \\
\hline Political character & British progressive. & British conservative. \\
\hline $\begin{array}{l}\text { Commencement } \\
\text { locations }\end{array}$ & Hobart, Melbourne. & Sydney. \\
\hline $\begin{array}{l}\text { Mobilisational } \\
\text { orientation } \\
\text { (King 1982) }\end{array}$ & $\begin{array}{l}\text { Major decentralization followed } \\
\text { by partial centralization. }\end{array}$ & Partial centralisation. \\
\hline Key manifestations & $\begin{array}{l}\text { Colonial separation and new state } \\
\text { movements; } 20^{\text {th }} C \text { Federal } \\
\text { Reconstruction Movements. }\end{array}$ & $\begin{array}{l}\text { Australian federation/unification } \\
\text { movements generally. }\end{array}$ \\
\hline Present at Federation? & Yes (Chapter VI). & Yes. \\
\hline Balance achieved? & $\begin{array}{l}\text { Arguably, not yet (no substantial } \\
\text { territorial decentralization since } \\
\text { 1859). }\end{array}$ & $\begin{array}{l}\text { Arguably, not yet (decentralization } \\
\text { demands remain unsatisfied by } \\
\text { centralized surrogates). }\end{array}$ \\
\hline
\end{tabular}

In themselves these dual veins of federalism still do not necessarily represent a complete picture of the major territorial ideas embedded in Australian politics. As indicated, both in the 1840s-1850s and more recently there have been pervasive arguments for entirely nonfederal alternatives, which as further counterpoints can be presented elsewhere. Nevertheless the clearer distinction between Australia's first and second federalisms offers a new point of departure for some vexed debates. The mix of factors influencing Australia's original colonial subdivisions becomes a little clearer. The history of colonial separation and new state movements becomes easier and more important to interpret. Continuing tensions and overlaps between veins of regional political dissent become more complex, but more potentially rewarding to unpack and reconcile (Brown 2002a, b). The fact that British colonial policy and Australian communities were dealing with coherent theoretical options for national constitutional development earlier than assumed, challenges us to revive and continue such traditions. From these lessons, we might hold out hope for our capacity to imagine the continued evolution of federal ideas and constitutional systems, rather than always assuming that the status quo is the end of the federal story. 


\section{References}

Baker, D. W. A. (1985). Days of wrath: a life of John Dunmore Lang. Melbourne University Press, Carlton, Vic.

Banks, R. F. (1973). Maine Becomes a State: The Movement to Separate Maine from Massachusetts 1785-1820. New Hampshire Publishing / Maine Historical Society

Beer, S. H. (1993). To Make A Nation: The Rediscovery of American Federalism. Harvard University Press

Belshaw, J. (1982). "Ulrich Ellis: journalist, political agitator, and theorist, public servant and historian" Canberra Historical Journal 10: 16-22.

Blainey, G. (2000). The centenary of Australia's federation: what should we celebrate? Senate Federation Lecture, Parliament House, Canberra, 26 October 2000.

Blainey, G. (2001). “Time to redraw the lines on the map.” Courier-Mail Brisbane., 4 September 2001: 11.

Blomley, N. K. (1994). Law, Space and the Geographies of Power. New York, Guilford Press.

Bolton, G. C. and D. B. Waterson (1999). "The Colonies' Paths to Federation: Queensland", in H. Irving (ed.), The Centenary Companion to Australian Federation. Cambridge University Press: 93.

Brown, A. J. (2001a). “Inside the Magical Room: Queensland, Regionalism and Constitution-Making 1896-99” New Federalist 8: 41-53.

Brown, A. J. (2001b). "Can't Wait for the Sequel: Australian Federation as Unfinished Business" Melbourne Journal of Politics 27: 49-70.

Brown, A. J. (2002a). "After the party: public attitudes to Australian federalism, regionalism and reform in the 21st century” Public Law Review 13 (3): 171-190.

Brown, A. J. (2002b). "Subsidiarity or subterfuge? Resolving the future of local government in the Australian federal system” Australian Journal of Public Administration 61 (4): 24-42.

Brown, A. J. (2003). The Frozen Continent: The Fall and Rise of Territory in Australian Constitutional Thought 1815-2003. PhD Thesis, Griffith University.

Bryce, J. (1889). The American Commonwealth. Macmillan, London.

Cell, J. W. (1970). British Colonial Administration in the Mid-Nineteenth Century: the Policy -Making Process. Yale University Press, New Haven.

Clark, C. M. H. (1962a). A History of Australia (Volume 1). Melbourne University Press

Clark, C. M. H. (1962b). A History of Australia (Volume 2). Melbourne University Press

Cramp, K. R. (1914). The State and Federal Constitutions of Australia. Angus and Robertson, Sydney.

Crisp, L. F. (1978). The Australian Federal Labour Party 1901-1951. Hale and Iremonger, Sydney.

Davis, S. L. and J. R. V. Prescott (1992). Aboriginal frontiers and boundaries in Australia. Melbourne University Press

Davis, S. R. (1978). The Federal Principle: A Journey Through Time in Quest of a Meaning. University of California Press, Berkeley.

Davis, S. R. (1987). "The state of the states", in M. Birrell (ed.), The Australian States: Towards a Renaissance. Longman Cheshire, Melbourne.

de Garis, B. (1999). "The Colonies' Paths to Federation: Western Australia", in H. Irving (ed.), The Centenary Companion to Australian Federation. Cambridge University Press: 285.

de Tocqueville, A. (1835). Democracy in America. Vintage, New York.

Earl Grey (1853). The Colonial Policy of Lord John Russell's Administration. Richard Bentley, London.

Egerton, H. E. (1893). A Short History of British Colonial Policy. Methuen, London.

Elazar, D. J. (1997). “Contrasting unitary and federal systems.” International Political Science Review 18(3): 237-251.

Ellis, U. R. (1933). New Australian States. Endeavour Press

Fitzgerald, R. (1982). From the Dreaming to 1915: A History of Queensland. University of Queensland Press.

Fletcher, C. (1998). "Administering a Region or Governing a People? Federalism as a Safety Net in the Northern Territory", in Constitutional Foundations: Reconciling a Diversity of Interests in a new Northern Territory Constitution for the 21st Century, R. Gray (ed.) Darwin, North Australia Research Unit, Australian National University: 29.

Ford, R. T. (2001). "Law's Territory (A History of Jurisdiction)", in The Legal Geographies Reader: Law, Power 
and Space, N. Blomley, D. Delaney and R. T. Ford (eds). Oxford, Blackwell: 153, 200-217.

Freeman, E. A. (1863). History of Federal Government [In Greece and Italy]. Macmillan, London.

Galligan, B. (1981). "Federalism's ideological dimension and the Australian Labor Party” Australian Quarterly 53(2) (Winter 1981): 128-140.

Galligan, B. (1995). A federal republic: Australia’s constitutional system of government. Cambridge University Press

Garden, D. (1984). Victoria: A History. Nelson, Melbourne.

Glassner, M. I. (1993). Political geography. John Wiley \& Sons, New York.

Greenway, J. (1972). The Last Frontier: A Study of Cultural Imperatives in the Last Frontiers of America and Australia. Lothian Publishing, Melbourne.

Griffith, S. W. (1891). "Political Geography of Australia" Royal Geographical Society of Australasia Queensland Branch Journal 6: 68-81.

Hall, R. (1998). Abolish the States! Australia’s Future and a \$30 Billion Answer to our Tax Problems. PanMacmillan

Harman, G. (1992). "Intergovernmental Relations: Federal Systems", in Encyclopedia of Government and Politics, M. Hawkesworth and M. Kogan (eds), London, Routledge. I.

Hirst, J. (2000). The Sentimental Nation: The Making of the Australian Commonwealth. Oxford University Press, Melbourne.

Holmes, J. and C. Sharman (1977). The Australian Federal System. Allen \& Unwin, Sydney.

Holmes, J. M. (1932). “The 'New States' Idea and its Geographic Background” Australian Quarterly: 59-72.

Howell, P. A. (1986). "The South Australia Act 1834", in D. Jaensch (ed.), The Flinders History of South Australia: Political History. Wakefield Press, Adelaide: 26.

Hume, L. J. (1994). "Foundations of Populism and Pluralism: Australian Writings on Politics to 1860", in Australian Political Ideas. G. Stokes (ed.). Sydney, University of NSW Press: 22-76.

Hyam, R. (2002). Britain's Imperial Century 1815-1914: A Study of Empire and Expansion. Cambridge, Palgrave Macmillan.

Irving, H. (ed.) (1999a). The Centenary Companion to Australian Federation. Cambridge University Press, Melbourne.

Irving, H. (1999b). To Constitute a Nation: A Cultural History of Australia's Constitution. Cambridge University Press

Jeans, D. N. (1972). An Historical Geography of New South Wales to 1901. Reed

Jensen, M. (1940). The Articles of Confederation: An interpretation of the socio-constitutional history of the American Revolution 1774-1781. University of Wisconsin Press

Joske, P. E. (1967). Australian Federal Government. Butterworths, Sydney.

Keith, A. B. (1938). The Dominions as Sovereign States: Their Constitutions and Governments. Macmillan, London.

Kidd, D. A. (1957). Latin-English English-Latin Dictionary. London, Collins.

Kidd, G. A. (1974). “New Cities - An End to New States” Australian Quarterly 46(2) (June 1974): 57-68.

King, P. (1982). Federalism and Federation. Croom Helm, London.

Knox, B. A. (1971). "Moreton Bay Separation: A Problem of Imperial Government 1825-1856" Historical Studies 14: 561-578.

Kociumbas, J. (1992). Oxford History of Australia: Possessions (Volume 2: 1770-1860). Oxford University Press, Melbourne.

Lumb, R. D. (1991). The Constitutions of the Australian States. University of Queensland Press

Macintyre, S. (1999a). A Concise History of Australia. Cambridge University Press

Macphee, I. (1994a). "Challenges for 21st century Australia: politics, economics and constitutional reform" Griffith Law Review 3: 245.

Macphee, I. (1994b). Towards a model for a two-tier government. Australian Federalism: Future Directions, Structural Change, University of Melbourne, July 1994, Centre for Comparative Constitutional Studies.

Manning, H. T. (1966). British Colonial Government After the American Revolution 1782-1820. Hamden, Connecticut, Archon.

Martin, G. (1972). The Durham Report and British Policy. Cambridge University Press 
McCarty, J. W. (1978). “Australian Regional History” Historical Studies 18 (70): 88-105.

McKenna, M. (1996). The Captive Republic: A History of Republicanism in Australia 1788-1996. Cambridge University Press, Melbourne.

McLelland, M. H. (1971). “Colonial and State Boundaries in Australia” Australian Law Journal 45: 671-679.

McMinn, W. G. (1979). A Constitutional History of Australia. Oxford University Press.

Melbourne, A. C. V. (1963). Early Constitutional Development in Australia. University of Queensland Press, St Lucia.

Melbourne Conference (1890). Official Record of the Proceedings and Debates of the Australasian Federation Conference, 1890. Robert S. Brain, Government Printer, Melbourne.

Melville, H. (1835). The History of Van Diemen's Land From the Year 1824 to 1835 Inclusive. HorwitzGrahame, 1965 Edition (G. Mackeness ed.), Sydney.

Morris, C. (2001). "Constitutional Dreaming", in C. Sampford and T. Round (eds), Beyond the Republic: Meeting the Global Challenges to Constitutionalism. Federation Press: 290-299.

Neale, R. G. (1950). “New States Movement” Australian Quarterly September 1950: 9-23.

Nicholas, H. S. (1951). “Fifty Years of the Constitution” Australian Quarterly June 1951: 29-34.

Nicholas, H. S. (1952). The Australian Constitution. Law Book Company, Sydney.

NSW Legislative Council (1853a). "Report from the Select Committee on the New Constitution” New South Wales Legislative Council Papers 2: 117-122.

NSW Legislative Council (1853b). "Constitution Bill: Petition from Shoalhaven” New South Wales Legislative Council Papers 2: 726; Sydney Morning Herald 7 December 1853, 3.

Page, E. C. G. (1917). “A Plea for Unification: the development of Australia.” Daily Examiner. Grafton, 1 September 1917.

Page, E. C. G. (1963). Truant surgeon: the inside story of forty years of Australian Political life. Angus and Robertson, Sydney.

Parkes, H. (1892). Fifty Years in the Making of Australian History. Longmans Green and Company, London.

Patapan, H. (2003). "Melancholy and Amnesia: Tocqueville's Influence on Australian Democratic Theory." Australian Journal of Politics and History 49(1): 1-16.

Pike, D. (1957). Paradise of Dissent: South Australia 1829-1857. Melbourne University Press

Prescott, J. R. V. (1987). "New state movements", in J. C. R. Camm and J. McQuilton (eds), Australians: A Historical Atlas. Fairfax, Syme \& Weldon, Sydney, 6: 257, 286.

Priestley, S. (1989). "Melbourne: A Kangaroo Advance", in P. Statham (ed.), The Origins of Australia's Capital Cities. Cambridge University Press, Cambridge: 216.

QPD (1899). Queensland Parliament Debates: Special Session - Federation Enabling Bill, Vol. 81.

Quartly, M. (1999). "The Colonies' Paths to Federation: Victoria", in H. Irving (ed.), The Centenary Companion to Australian Federation. Cambridge University Press: 220.

Riker, W. H. (1975). "Federalism", in Handbook of Political Science, F. E. Greenstein and N. W. Polsby (eds), Reading, Addison-Wesley.

Roberts, S. H. (1924). History of Australian Land Settlement. Macmillan (1968 ed.), Melbourne.

Robson, L. (1989). "Settling Van Diemen's Land", in P. Statham (ed.), The Origins of Australia's Capital Cities. Cambridge University Press, Cambridge: 79.

Rossiter, C. (1953). Seedtime of the Republic: The Origin of the American Tradition of Political Liberty. Harcourt, Brace and World, New York.

Saunders, C. (2001). "Dividing Power in a Federation in an Age of Globalisation", in C. Sampford and T. Round (eds), Beyond the Republic: Meeting the Global Challenges to Constitutionalism. Federation Press: 129-145.

Sawer, G. (1969). Modern Federalism. Watts \& co, London.

Sharman, C. (1987). "Coping with the future", in M. Birrell (ed.), The Australian States: Towards a Renaissance. Longman Cheshire, Melbourne.

Shaw, A. (1989). "The Founding of Melbourne", in P. Statham (ed.), The Origins of Australia's Capital Cities. Cambridge University Press, Cambridge: 199.

SMH (1853a). "Constitution: Summary of Proposals.” Sydney Morning Herald. Sydney, 6 December 1853: 4.

SMH (1853b). “New Constitution.” Sydney Morning Herald. Sydney, 26 August 1853: 4. 
SMH (1853c). "Legislative Council Debate: Moreton Bay.” Sydney Morning Herald. Sydney, 27 August 1853: 3.

Statham, P. (1981). "Swan River Colony 1829-1850", in C. T. Stannage (ed.), A New History of Western Australia. University of Western Australia Press, Perth: 181.

Townsley, W. A. (1991). Tasmania: From Colony to Statehood 1803-1945. St David's Park

Walter, B. J. and M. Huebsch (1978). "The Spatial Conditions of Federalism.” Ohio Geographers: Recent Research Themes 6: 51.

Ward, J. M. (1958). Earl Grey and the Australian Colonies 1846-1857. Melbourne University Press

Warden, J. (1992). "Federalism and the Design of the Australian Constitution” Australian Journal of Political Science 27 (Special Issue): 143-158.

Warden, J. (1999). "The Colonies' Paths to Federation: Tasmania", in H. Irving (ed.), The Centenary Companion to Australian Federation. Cambridge University Press: 187.

Watts, R. (1996). Comparing Federal Systems in the 1990s. Institute of Intergovernmental Relations Queen's University, Kingston.

Wentworth, W. C. (1956). "Responsible Government in Australia: State Constitutions and Federal Power" Australian Quarterly 28(2), June: 7-19.

Williams, J. (1999). Click Go The Shears: The Reception of Constitutional Models and Australian Constitutional Theory. Constitutionalism, Universalism and Democracy: Fifth World Congress of the International Association of Constitutional Law, Rotterdam, The Netherlands, 12-16 July 1999.

Williams, J. (2001). "The Australian Constitution and the Challenge of Theory", in C. Sampford and T. Round (eds), Beyond the Republic: Meeting the Global Challenges to Constitutionalism. Federation Press: 119-128.

Wood, F. L. W. (1933). Constitutional Development of Australia. Harrap \& Co, Sydney. 